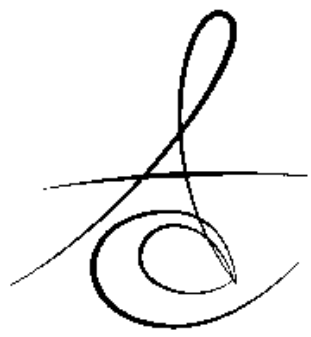

\title{
TROMBOSİT KONSANTRELERİNİN DİŞETI ÇEKİLMELERİNİN TEDAVİSİ AMACIYLA KULLANIMLARI: DERLEME
}

\section{APPLICATION OF PLATELET CONCENTRATES FOR THE TREATMENT OF GINGIVAL RECESSION DEFECTS: REVIEW}

Yrd. Doç. Dr. Serap KARAKIş*

\author{
Prof. Dr. Berrin ÜNSAL ${ }^{* *}$
}

Makale Kodu/Article code: 2627

Makale Gönderilme tarihi: 19.02.2016

Kabul Tarihi; 08.06.2016

\section{ÖZET}

Dişeti çekilmelerinin tedavisi amacıyla pek çok cerrahi teknik ve materyal tanımlanmıştır. Tüm bu yöntemlerin geliştirilmesindeki amaç operasyon sonrası hasta konforunu arttırmak, operasyon süresini kısaltmak, komplikasyon gelişmesini engellemek ve tam kök kapanmasını sağlamak olarak sıralanabilir. Son dönemlerde açık kök yüzeylerinin örtülmesinde trombosit konsantreleri tek başına ya da subepitelyal bağ dokusu grefti, aselüler dermal matriks allogrefti, kollajen sponge ya da mine matriks proteinleri ile birlikte kullanılmakta ve klinik çalışmalarla sonuçları değerlendirmektedir. Bu derlemenin amacı açık kök yüzeylerinin kapatılması için kullanılan trombosit konsantrelerinin tanitılması ve konuyla ilgili olarak yapılan çalışmaların sonuçlarının değerlendirilmesidir.

Anahtar Kelimeler: dişeti çekilmesi, çekilme tedavisi, trombositler, büyüme (farklılaşma) faktörleri

\section{ABSTRACT}

Many surgical techniques and materials have been identified for the purpose of gingival recession treatment. The aims of all these methods can be listed to improve patient comfort after surgery, short the operation time, prevent complications, and provide full root coverage. Nowadays, platelet concentrates are used alone or with subepithelial connective tissue graft, acellular dermal matrix allograft, collagen sponge or enamel matrix proteins in covering the exposed root surface and evaluated outcomes with clinical studies. The purpose of this review is to introduce of the use platelet concentrates and evaluate the results of studies with platelet concentrates to cover denuded root surfaces.

Keywords: gingival recession, withdrawing treatment, platelets, growth (differentation) factors

\section{TROMBOSİT KONSANTRELERİ}

Trombositler, kemik iliğinde bulunan megakaryositlerden köken almakla beraber yaşam süreleri 8-10 gün arasında değişen çekirdeksiz hücrelerdir. ${ }^{1,2}$ Trombositler alfa granüller, lizozomlar, dense granüller olmak üzere 3 çeşit vezikül içermektedir. Dense granüllerde; seratonin, histamin, dopamin gibi katekolaminler ile adenozin di-phosphate, kalsiyum bulunurken, lizozomal granüller ise asit hidrolaz, katepsin D ve $E$, elastaz ve diğer degradasyon yapan enzimleri içermektedir. ${ }^{3}$ Alfa granülleri içeriği açısından diğer veziküllere göre daha yoğundur. Tablo 1'de görüldüğü gibi alfa granüllerin içerisinde bulunan içerik, adeziv proteinler, pıhtılaşma faktörleri, fibrinolitik faktörler, proteazlar ve anti-proteazlar, büyüme faktörlerisitokinler ve kemokinler, temel yapı proteinleri, antimikrobiyal proteinler ve membran glikoproteinleri olarak sınıflandırılabilir. ${ }^{2,3}$

Yara iyileşmesi pıhtı oluşumu ve yara bölgesindeki iyileşmede rol alan büyüme faktörlerinin serbest bırakılmasını sağlayacak trombosit degranülasyonu ile başlar. ${ }^{2}$ Degranülasyon, iyileşmenin ilk aşamalarında fibrin matriksin proliferasyonunu ve hücre migrasyonunu stimüle edecek diğer sitokinlerin de salınımını sağlamaktadır. Trombositlerden salınan büyüme faktörlerinin pek çok hücre tipinin migrasyonu, proliferasyonu, stimülasyonu için önemlidir. ${ }^{1} \mathrm{Bu}$ büyüme faktörlerinden trombosit kaynaklı büyüme faktörü (TKBF), dönüştürücü büyüme faktörü beta-1(DBF- $\beta 1)$,

\footnotetext{
*İstanbul Aydın Üniversitesi, Diş Hekimliği Fakültesi, Periodontoloji AD.

** Gazi Üniversitesi, Diş Hekimliği Fakültesi, Periodontoloji AD.
} 
Tablo 1. Alfa granül içeriği $i^{2,3}$

\begin{tabular}{|c|c|}
\hline Kategori & Biyolojik aktiviteleri \\
\hline Adeziv proteinler & $\begin{array}{l}\text { Hücre teması etkileşimleri, pıhtılaşma, } \\
\text { ekstraselüler matriks kompozisyonu }\end{array}$ \\
\hline $\begin{array}{l}\text { PIhtılaşma } \\
\text { faktörleri ve } \\
\text { ilişkili proteinler }\end{array}$ & Trombin üretimi ve düzenlenmesi, anjiogenezis \\
\hline $\begin{array}{l}\text { Fibrinolitik } \\
\text { faktörler ve ilişkili } \\
\text { proteinler }\end{array}$ & Plazmin üretimi ve vasküler remodelizasyon \\
\hline $\begin{array}{l}\text { Proteazlar ve } \\
\text { anti-proteazlar }\end{array}$ & $\begin{array}{lr}\begin{array}{l}\text { Anjiogenezis, vasküler } \\
\text { koagülasyonun }\end{array} \\
\text { hücresel davranışın düzenlenmesi }\end{array}$ \\
\hline $\begin{array}{l}\text { Büyüme } \\
\text { faktörleri- } \\
\text { sitokinler ve } \\
\text { kemokinler }\end{array}$ & $\begin{array}{l}\text { Kemotaksis, hücre proliferasyonu ve } \\
\text { farklılaşması, anjiogenezis }\end{array}$ \\
\hline $\begin{array}{l}\text { Temel yapı } \\
\text { proteinleri }\end{array}$ & $\begin{array}{lcc}\text { Anjiogenezisin düzenlenmesi, } & \text { vasküler } \\
\text { remodelizasyon, hücresel etkileşimler } & \\
\end{array}$ \\
\hline $\begin{array}{l}\text { Anti-mikrobiyal } \\
\text { proteinler }\end{array}$ & Bakterisidal ve fungisidal özellikler \\
\hline $\begin{array}{l}\text { Membran } \\
\text { glikoproteinleri }\end{array}$ & 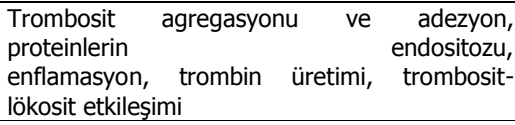 \\
\hline
\end{tabular}

damarsal endotelyal büyüme faktörü(DEBF), fibroblast büyüme faktörü(FBF), epidermal büyüme faktörü(EBF) ve insülin benzeri büyüme faktörünün(İBBF) yara iyileşmesi için anahtar görevinde oldukları ve hücre anjiogenezisini, proliferasyonu, ekstraselüler matriks yapımını ve remodelizasyonu geliştirdikleri bildirilmiştir. ${ }^{3}$ Trombositlerden salınan başlıca büyüme faktörleri ve görevleri Tablo 2'de sıralanmaktadır. ${ }^{2}$

Kan kaynaklı ürünler, yara yüzeylerinin örtülmesi ve iyileşmesinin stimüle edilmesi amacıyla kullanılmaktadır. Bunun için ilk olarak insan plazmasından elde edilen fibrin yapışıııııları(FY) kullanıımışıı. ${ }^{4,5} \mathrm{FY}$ veya fibrin doku adhezivleri fibrin pıhtısının oluşumunda kanın koagülasyonunun son aşamalarını taklit ederler ve insan plazmasından elde edilirler. ${ }^{5}$ Polimerizasyonu trombin ve kalsiyum ile başlatılır. FY'nin ticari preparat adı Tisseel(Baxter, USA)'dir. Ancak, FY ticari preparat olarak kontaminasyon riski oluşturmaktadır. Otolog FY'nin hazırlanması ise uzun sürmektedir, karışık işlemler gerektirmektedir ve oldukça maliyetlidir. ${ }^{4,5}$

FY greftlenen veya yaralanan dokularda iyileşmenin hızlandırılması ve süturlarla birlikte daha iyi bir yara kapanmasının sağlanmasında kullanıı.ır. FY kardiyovasküler cerrahide, toraks cerrahisinde, oftalmik cerrhide, nörocerrahide, oral ve maksillofasiyal cerrahide kullanılmaktadır. Ayrıca, periodontal cerrahide greftlerin sabitlenmesinde rekonstrüktif işlemlerin geliştirilmesi amacıyla da kullanıldıkları bildirilmiştir. ${ }^{5}$ Ancak, devam eden süreçte trombosit konsantreleri; iyileşmeye daha iyi katkı sağlanması amacıyla FY yerine kullanılmıştır. ${ }^{4}$

Büyüme faktörlerini içeren rejeneratif tedavi yöntemlerinin; kemik defektlerinin tamirinde, kist kavitelerinde, furkasyon problemlerinin tedavilerinde ve yumuşak dokuyu içeren cerrahilerde kullanılabileceği belirtilmiştir. ${ }^{3,6-9}$ Trombosit konsantreleri; anjiogenezisi hızlandırmakta bununla birlikte osteoblast ve fibroblast aktivitesini stimüle etmektedirler. Rejenerasyonun sağlanması ve iyileşmenin hızlanması için gereken anahtar hücreler ile büyüme faktörlerini içermelerinden dolayı periodontoloji ve implantoloji alanında kullanılmaktadırlar. ${ }^{10-12}$

Trombosit konsantrelerinin ilk kuşağı Trombositten zengin plazmadır(TZP). TZP diş hekimliğinde ilk olarak Marx ve arkadaşları tarafından büyüme faktörleriyle tedavi konsepti olarak sunulmuştur. ${ }^{4}$ TZP elde etmek için pek çok santrifüj cihazı, protokol ve kit geliştirilmiştir. Elde edilen ürünlerin hepsi protokollerde farkllık olmasına rağmen TZP olarak adlandırılmıştır. Bu ürünlerde ortak olan bazı özellikler; kanın cerrahi işlemden önce veya işlem sırasında antikoagülan ile alınması ve hemen santrifüje edilmesi, işlemin yaklaşık olarak 1 saat sürmesi, birbirini takip eden 2 santrifüj işleminin sonunda kırmızı kan hücrelerinin ve trombositten fakir plazma(TFP)'nin uzaklaştırlarak sadece ortada bulunan "buffy coat" tabakasının enjektör yardımı ile alınarak trombin veya kalsiyum klorid ile aktive edilmesini takiben cerrahi bölgesine aktarıması olarak sıralanabilir. ${ }^{4}$

2001 yllinda Choukroun ${ }^{13}$ tarafindan tanitilan trombositten zengin fibrin(TZF) ikinci kuşak trombosit konsantresidir. Protokolünde herhangi bir antikoagülan ve sığır trombini kullanılmadan kan alınmakta ve hemen santrifüj edilerek doğal polimerizasyon süreci oluşturulmaktadır. $10 \mathrm{ml}$ 'lik tüpe alınan venöz kan yaklaşık 10 dakika ve $3000 \mathrm{rpm}$ (yaklaşık olarak 400 g)'de olmak üzere santrifüj edilir. Kullanılan cihaz, PC02 santrifüj cihazı ve kiti (Process, Nice, France)'dir. ${ }^{1,13-15}$ Tek aşamalı santrifüj sonrası tüpte üstte yer alan trombositten fakir plazma(TFP) ile en altta yer alan kırmızı kan hücresi(KKH) arasında TZF yer almaktadır. Teknik basit ve diğer yöntemlere göre daha az maliyetlidir. ${ }^{8}$ TZF; otolog bir fibrin matrikstir, uygun 
Atatürk Üniv. Diş Hek. Fak. Derg.

KARAKIŞ, ÜNSAL

J Dent Fac Atatürk Uni

Supplement: 16, YIl: 2016,Sayfa : 85-98

Tablo 2. Büyüme faktörleri ve yara iyileşmesindeki görevleri

\begin{tabular}{|c|c|}
\hline Büyüme faktörü & Yara iyileşmesi ve doku oluşturma yeteneği \\
\hline $\begin{array}{l}\text { Epidermal büyüme faktörü } \\
\text { (EBF) }\end{array}$ & $\begin{array}{l}\text { - Epidermal ve epitelyal hücrelerin, fibroblastların ve emriyojenik hücrelerin proliferasyonunu } \\
\text { stimüle eder. } \\
\text { - Fibroblastlar ve epitelyal hücreler için kemoatraktandır, } \\
\text { - Re-epitelizasyonu stimüle eder, anjiogenezisi arttırır. } \\
\text { - Ekstraselüler matriks yenilenmesi (turn-over) ve sentezini etkiler. }\end{array}$ \\
\hline $\begin{array}{l}\text { Trombosit kaynaklı büyüme faktörü } \\
\text { ( TKBF) }\end{array}$ & $\begin{array}{l}\text { - A ve B izoformları fbroblastlar, arteriyel düz kas hücreleri, kondrositler ve epitelyal, } \\
\text { endotelyal hücreler için mitojendir. } \\
\text { - Hematopoetik ve mezenşimal hücreler, fibroblastlar ve kas hücreleri için güçlü kemoatraktan } \\
\text { etkisi vardır. } \\
\text { - DBF- } \beta \text { 'yı aktive eder, nötrofil ve makrofajları, fibroblast ve düz kas hücrelerinin } \\
\text { mitognenezisini, kollajen sentezini, kollajenaz aktivitesini ve anjiogenezisi stimüle eder. }\end{array}$ \\
\hline $\begin{array}{l}\text { Dönüştürücü büyüme faktörü alfa (DBF- } \\
\text { a) }\end{array}$ & $\begin{array}{l}\text { - EBF ile benzer özelikleri taşır, aynı reseptöre bağlanır. } \\
\text { - Mezenşimal, epitelyal, endotelyal hücre büyümesini, endotelyal kemotaksisi uyarır, epidermal } \\
\text { büyümeyi kontrol eder. } \\
\text { - EBF'den daha güçlü olmak üzere endotelyal hücrelerin proliferasyonunu uyarır } \\
\text { Osteoblast üretimini destekler. } \\
\text { - Kollajen sentezinin inhibisyonu ve kalsiyumun serbest bırakılması aracılığı ile kemik } \\
\text { oluşumunu ve remodelizasyonunu etkiler. }\end{array}$ \\
\hline $\begin{array}{l}\text { Dönüştürücü büyüme faktörü beta } 1 \\
\text { (DBF-ß1) }\end{array}$ & $\begin{array}{l}\text { - Fibroblast kemotaksisini ve proliferasyonunuve kollajen sentezini uyarır. } \\
\text { - Dermal skar oluşumunu azaltır epitelyal ve endotelyal hücreler, fibroblastlar, nöronal } \\
\text { hücreler, hematopoetik hücreler ve keratinositler için büyüme inhibitörüdür. } \\
\text { - FBF, EBF, TKBF byiolojik aktivitelerini antagonize eder. }\end{array}$ \\
\hline $\begin{array}{l}\text { Keratinosit büyüme faktörü veya } \\
\text { fibroblast büyüme faktörü-7(FBF-7) }\end{array}$ & $\begin{array}{l}\text { - Deri keratinositleri için en güçlü büyüme faktörüdür, deri yaralanmalarını takip eden doku } \\
\text { tamiri olaylarında görev alır. } \\
\text { • Proliferasyon, diferansiasyon, anjiogenezis, hücre göçü aracılığı ile yara iyileşmesini } \\
\text { destekler. } \\
\text { • Çoğu epitelyal hücre için mitojenken fibrobalast ve endotelyal hücreler için mitojenik özellik } \\
\text { göstermez. }\end{array}$ \\
\hline $\begin{array}{l}\text { Fibroblast büyüme faktörü asidik (FBF- } \\
\text { 1, FBFa) }\end{array}$ & $\begin{array}{l}\text { - Proliferasyon, diferansiasyon, anjiogenezis ve hücre göçüne katılır. } \\
\text { - Deri kaynaklı keratinositler, dermal fibroblastlar ve damarsal endotelyal hücreler için mitojen } \\
\text { özellik gösterir. }\end{array}$ \\
\hline $\begin{array}{l}\text { Fibroblast büyüme faktörü-temel (FBF- } \\
\text { 2) }\end{array}$ & $\begin{array}{l}\text { - Fibroblastların, miyoblastların, osteoblastların, nöronal hücrelerin, endotelyal hücrelerin, } \\
\text { keratinositlerin, kondrositlerin büyümesini uyarır. } \\
\text { - Endotelyal hücre proliferasyonunu, kollajen sentezini, yara kontraksiyonunu, matriks } \\
\text { sentezini, epitelizasyonunu ve keratinosit büyüme faktörünün üretimini uyarır. }\end{array}$ \\
\hline $\begin{array}{l}\text { Damarsal endotelyal büyüme faktörü } \\
\text { (DEBF) }\end{array}$ & $\begin{array}{l}\text { - Makrovasküler endotelyal hücre proliferasyonunu uyarır. } \\
\text { - Güçlü bir anjiojenik proteindir, yeniden damarlanmayı indükler. } \\
\text { - Metalloproteinaz sentezini indükler, dokular arasındaki tip 1,2 ve } 3 \text { kollajen üretimini azaltır. }\end{array}$ \\
\hline Bağ dokusu büyüme faktörü (BDBF) & $\begin{array}{l}\text { - Vasküler endotelyal hücrelerin proliferasyonunu, göçlerini ve anjiogenezisi indükler. } \\
\text { - Osteoblastların farklılaşması ve proliferasyonu için güçlü bir uyarandır, matriks } \\
\text { mineralizayonlarını uyarır. }\end{array}$ \\
\hline $\begin{array}{l}\text { Granülosit-makrofaj koloni-stimüle edici } \\
\text { faktör }\end{array}$ & $\begin{array}{l}\text { - Osteoblastların proliferasyonunu ve farklılaşmasını uyarır. } \\
\text { - Nötrofiller için güçlü bir kemoatraktandır. }\end{array}$ \\
\hline İnsülin benzeri büyüme faktörü (İBBF) & $\begin{array}{l}\text { - Fibroblastlar için büyüme faktörüdür, in vitro olarak mesodermal hücre türleri üzerine } \\
\text { mitojenik etkisi vardır. } \\
\text { - Fibroblastlardan prostaglandin E2 ve kollajenaz sentezini arttırır. } \\
\text { - Kemik hücreleri aracılığı ile kollajen ve matriks sentezini uyarır ve eklem kıkırdaklarının } \\
\text { metabolizmalarını düzenler. }\end{array}$ \\
\hline Tümör nekroz faktör alfa ( TNF- a) & • $\quad$ Fibroblastlar için büyüme faktörüdür ve anjiogenezisi arttırır. \\
\hline İnterlökin 1 beta ( IL-1ß) & $\begin{array}{l}\text { - Endotelyal hücrelerin ve hepatositlerin büyümesini inhibe eder. } \\
\text { - Osteoklastları aktif hale getirerek, yeni kemik oluşumunu baskılar. } \\
\text { - Düşük konsantrasyonlarda ise yeni kemik oluşumunu arttırabilir. } \\
\text { - Enflamatuvar olayları ve kollajenaz aktivitesini geliştirir. }\end{array}$ \\
\hline İnterlökin 8 ( IL-8) & - Anjiogenezisi destekler ve epidermal hücreler için mitojeniktir. \\
\hline
\end{tabular}


iyileşmeye izin veren bütün moleküler ve hücresel elemanları içerir. Bununla birlikte fizyolojik iyileşmeyi de hızlandırır. ${ }^{15}$ TZP'den farklı olarak hızlı çözünmeyen dayanıklı bir fibrin ağ yapısı sergilediği, yüksek oranda trombosit, lökosit ve büyüme faktörü içeren bir matriks sağladığı da gösterilmiştir. ${ }^{16}$

Tunalı ve arkadaşları ${ }^{17,18}$ son dönemlerde yaptıkları çalışmalarda TZF elde edilmesinde kullanılan tüpler yerine tip IV titanyumdan ürettikleri tüplere kanın alınarak santrifüj edilmesini önermişlerdir. Kullandıkları tekniği "titanyum hazırlıklı-TZF (T-TZF)" protokolü olarak adlandırmışlardır. Titanyumun biyouyumlu, korozyona dirençli ve kanla temas edince gösterdiği uyumlu yapısının santrifüj sonunda elde edilen T-TZF yapısının, cam tüplerde elde edilen TZF' ye göre daha iyi bir fibrin polimerizasyonu gösterdiği, T-TZF'de bulunan fibrin yapısının yapılan histomorfometrik analizler ve elektron mikroskobu taraması ile değerlendirilmesi sonucunda normal TZF protokolüne göre daha kalın ve yoğun bir fibrin ağ yapısının elde edilmesini sağladığını bildirmişlerdir. ${ }^{18}$

TZF protokolünden farklı olarak geliştirilen diğer bir protokol(A-PRF: Advanced Platelet Rich Fibrine) $1500 \mathrm{rpm}$ ve 14 dakika olarak uygulanmaktadır. ${ }^{19}$ Normal TZF protokolüne göre santrifüj dönüş hızının azalması ve santrifüj süresinin artması ile nötrofilik granülositlerin pıhtıdaki dağılımının sadece "buffy coat"-kırmızı hücre sınırında değil daha distal bölümlere doğru yaygınlık göstermesinin sağlandığı bildirilmiştir. $\mathrm{Bu}$ durumun kemik ve yumuşak doku rejenerasyonunda A-PRF monosit ve makrofajları kaynaklı büyüme faktörlerinin daha fazla rol almasını sağlayacağı bildirilmiştir. ${ }^{19}$

2006 yılında Sacco $^{20}$ tarafından tanıtılan konsantre büyüme faktörü(KBF) protokolü, TZF protokolüne benzemekle beraber kullanılan santrifüj cihazı farklıdır. KBF konsantre halde büyüme faktörü içeren trombositten zengin fibrin matriks üretilmesi için yenilikçi bir metot ya da yeni nesil bir trombosit konsantresi olarak da tanımlanmaktadır. Klinik ve in vitro çalışmalar ile yeni araştırılmaya başlanmıştır. ${ }^{21-23}$ KBF'nin de elde edilmesinde TZF'de olduğu gibi sığır trombini ve antikoagülan gibi kimyasal veya allerjenik ek madde kullanımı gerekmemektedir. Bu sebeplerle, TZF ve KBF'de viral hastalık geçişi olmamaktadır. ${ }^{20,24}$ KBF'de kullanılan santrifüj cihazının dönüş hızı, venöz kandan hücreleri ayırmak için 2400-3000 rpm arasında değişkenlik göstermektedir. ${ }^{21-23,25-26}$ Santrifüj sırasında dönüş hızının değişkenlik göstermesi ile TZF'den daha geniş, yoğun ve büyüme faktöründen daha zengin bir fibrin matriksin elde edildiği düşünülmektedir. 20-22,27

Dohan Ehrenfest ve arkadaşları derlemelerinde, günümüzde mevcut olan trombosit konsantrelerinin elde edilmesinde kullanılan yöntemleri; lökosit içeriği ve fibrin yapısını temel alarak sınıflandırmışlardır. Likit trombosit konsantre süspansiyonları (aktivasyon öncesi) TZP olarak adlandırıırken, daima aktif halde bulunan ve daha solid yapıda olan trombosit konsantreleri ise TZF olarak adlandırılmıştır. Ayrıca TZP ve TZF ıökosit içerip içermemesine göre de sınıflandırılmıştır. Choukroun tarafından tanıtılan TZF lökosit içermektedir. $^{4,28-29}$ Bu sınıflamaya göre A-PRF, T-TZF ve KBF solid yapıda olmalarından dolayı TZF olarak da tanımlanabilirler veya ayrı bir sınıflama sistemi oluşturulması gerekebilir.

\section{DİŞETİ ÇEKİLMELERİNİN TEDAVİLERİ}

Dişeti çekilmesi, dişeti kenarının mine sement birleşiminin(MSB) apikaline doğru yer değiştirmesi sonucu kök yüzeyinin klinik olarak ortaya çıkması olarak tanımlanmaktadır. ${ }^{30}$ Dişeti çekilmesi; anatomik, patolojik ve travmatik faktörlerin sonucunda meydana gelmektedir. ${ }^{31}$ Dişeti çekilmesinin beraberinde getirdiği sorunlar; dentin hassasiyeti ${ }^{32}$, plak birikimi ve plağın uzaklaştırılması için gerekli hijyenin sağlanamaması ${ }^{33}$, estetik sorunlar ${ }^{33}$, kök çürükleri ${ }^{34,35}$, diş kaybetme korkusu $^{31}$ ve abrazyon ${ }^{31}$ olarak sayılabilir. ${ }^{36}$

Dişeti çekilmelerinin tedavisi amacıyla; laterale kaydırılan flep, kuronale kaydırılan flep(KKF), çift papil tekniği, serbest dişeti grefti, subepitelyal bağ dokusu grefti (SBDG), aselüler dermal matriks allogrefti (ADMA), mine matriks proteini(EMD) olmak üzere pek çok teknik geliştirilmiştir. ${ }^{36,37}$ Bu tekniklerden SBDG'nin kök kapanması ve keratinize doku kazancının sağlanmasında diğer tekniklere göre daha başarılı ve tedavi sonuçlarının öngörülebilirliği açısından daha iyi olduğu bildirilmiştir. SBDG, KKF tekniği ile birlikte altın standart olarak kabul görmüştür. ${ }^{38-41}$ Ancak bu tekniğin çeşitli dezavantajları bulunmaktadır. Bunlar; bazı durumlarda verici sahanın doku kalınlığının fazla olmasının gerekmesi, ikinci bir cerrahi bölgenin varlığı nedeniyle risk oluşturması, cerrahi işlem süresinin uzaması, verici bölge olarak premolar-molar palatinal bölgede MSB'ye damar sinir paketinin yakın olması, çoklu defekt veya geniş çekilme sahalarının varlığı durumunda verici sahadan fazla greft alınamamasıdır.

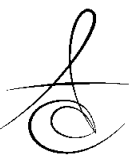


Aynı zamanda, cerrahi işlemler sonrasında ağrı, kanama ve hasta konforunda azalma da görülmetedir. Bu nedenlerden dolayı dişeti çekilmelerinin tedavilerinde alternatif yöntemler geliştirilmiştir. EMD, ADMA, trombosit konsantreleri ise bunlardan bazllarıdır. ${ }^{6,42-43}$

\section{Trombosit Konsantrelerinin Periodontal Plastik Cerrahide Kullanıldığı Çalışmalar}

Trombositten Zengin Plazma: Jankovic ve arkadaşlarııın $^{44}$ çalışmasında, hastalarda bilateral olarak bulunan Miller sınıf I ve II tekli veya çoklu dişeti çekilmeleri, TZP+SBDG+KKF veya SBDG+KKF tekniği kullanılarak tedavi edilmiştir. Her iki grupta klinik ataşman seviyesi(KAS) başlangıca göre 6 . ayda anlamlı olarak azalmıştır ve gruplar arasında fark bulunamamıştır. TZP+SBDG grubunda ortalama KKY değerleri $\% 91,68 \pm 10,65$ ve SBDG grubunda ise $\% 88,96 \pm 15,46$ olarak kaydedilmiştir, gruplar arasında anlamlı farklıık bildirilmemiştir. TZP+SBDG grubunda, SBDG grubuna göre anlamlı olarak keratinize dişeti genişliğinde(KDG) daha fazla artış görülürken, ilk 5 gün için daha düşük ağrı skorları ve 1 . ve 2 . haftada daha yüksek iyileşme değerleri kayıt edilmiştir. Çalışmada, TZP'nin SBDG+ KKF tekniğine ek olarak kullanımasının doku iyileşmesini hızlandırdığı ve KDG'yi arttırdığı bildirilmiştir. ${ }^{44}$

Keçeli ve arkadaşlarının ${ }^{45}$ çalışmasında, oluşturulan iki hasta grubunda tekli defektlere, rastgele olarak SBDG+KKF ya da TZP+SBDG+KKF tekniği uygulan- mıştır. SBDG grubunda, 6. hafta, 6 . ve 12. aylarda kök kapanması yüzdesi (KKY) medyan değerleri sırasıyla $\% 85,4, \% 86,4, \% 86,4$, TZP + SBDG grubunda ise $\% 88,9, \% 88,1 \% 86,4$ olarak bildirilmiştir ve gruplar arasında anlamlı farklılığın olmadığını rapor etmişlerdir. Her iki grupta da KDG'de artış görülmüş ancak arala- rında anlamlı farklılık bildirilmemiştir. Çalışmada TZP'nin SBDG ile birlikte kullanılmasının ek bir yarar sağlamadığı, TZP'nin elde edilmesinin ve kök yüze- yinde sabit kalmasının güç olduğu ve bu nedenle cerrahi işlem süresini arttırdığı bildirilmiştir. ${ }^{45}$

Huang ve arkadaşlarının ${ }^{46}$ çalışmasında Miller sınıf I tekli dişeti çekilmesine sahip 24 hasta randomize olarak sadece KKF ya da KKF+TZP ile tedavi edilmiştir. Hastalar cerrahi sonrası 2., 4., 12. ve 24. haftalarda takip edilmişlerdir. 6 ay sonunda KKY değerleri, KKF grubunda $\% 83,5 \pm 21,8$ ve TZP+KKF grubunda ise $\% 81,0 \pm 28,7$ 'dir. Keratize dişeti kalınlığı(KDK) artışı
KKF grubunda anlamlı iken, KDG'de görülen artı̧̧ KKF+TZP grubunda daha anlamlı bulunmuştur. Miller sınıf I dişeti çekilmelerinin tedavisinde TZP'nin KKF'ye ek olarak kullanılmasının klinik olarak ölçülebilir ek bir yarar sağlamadığını rapor etmişlerdir. Cerrahiden 2 hafta sonraki iyileşmenin değerlendirilmesi için yara iyileşmesi indeksini kullanmışlardır. TZP+ KKF grubunun sadece KKF uygulanan gruba göre iyileşmesinin daha iyi olduğu ancak bu farkın istatistiksel anlama ulaşmadığını bildirmişlerdir. Küçük bir hasta grubunda çalışılmasının çalışma sonuçlarını etkilemiş olabileceği belirtilmiştir. ${ }^{46}$

Cheung ve Griffin ${ }^{6}$ çalışmalarında, 15 hastada bulunan bilateral Miller sınıf I ve II dişeti çekilmelerinin tedavisinde kullanımak üzere elde edilen TZP'yi alıcı bölgeye kollajen sponge (Collacote, Integra LifeSciences Co., Plainsboro, NJ) yardımı ile taşımış ve KKF ile örtmüşlerdir. Araştırmacılar TZP+kollajen sponge kombinasyonunu, "trombosit konsantresi grefti (TKG)" olarak tanımlamışlardır. Hastalarda bulunan diğer çekilme defektleri SBDG+KKF ile tedavi edilmiştir. 8. ayda ortalama KKY ve tam kök kapanması SBDG için $\% 95$ ve $\% 65,5$ iken TKG için $\% 80$ ve $\% 60$ olarak bildirilmiş, aralarında anlamlı farklılık bulunmamıştır. KDG artışı ise gruplar arasında anlamlı farklılık göstermemiştir. İlk bir hafta ve 1 aylık dönemdeki cerrahi işlemler sonrası konforsuzluk düzeyi, VAS ölçeği yardımıyla değerlendirilmiştir. 1. haftada VAS skorları arasında görülen fark istatistiksel öneme ulaşmazken, 1. ay sonuçları test grubu lehine anlamlı bulunmuştur. Çalışmanın 8 aylık sonuçlarına göre elde edilen trombosit konsantresinin TKG şeklinde uygulanmasının dişeti çekilmelerinin tedavisinde yeni bir seçenek olabileceği bununla birlikte renk, yüzey özellikleri ile konturun değerlendirildiği estetik değerlendirmede de daha iyi sonuçlar verdiği rapor edilmiştir. ${ }^{6}$

Griffin ve Cheung ${ }^{47}$ yapmış oldukları vaka serisi çalışmalarında, 6 hastada 37 dişte bulunan Miller sınıf I veya sınıf II dişeti çekilmesi defektlerinin tedavisinde TZP, TKG olarak açık kök yüzeyine yerleştirilerek üzerine kollajen membran (Ossix, Colbar, RamatHaSharon, Israel) yerleştirilmiş ve KKF ile örtülmüştür. Başlangıca göre 6. ayda cep derinliği, KAS ve çekilme derinliğinde(ÇD) önemli azalma olduğunu, 6. ve 36 . aylar arasında ise anlamlı bir değişim olmadığııı bildirmişlerdir. 6. ve 36. aylar arasında KDG'nin önemli

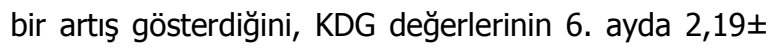
$0,96 \mathrm{~mm}, 36$. ayda ise $3,01 \pm 1,25 \mathrm{~mm}$ olduğunu rapor 
etmişlerdir. Ortalama KKY 6. ayda, \%89,86 $\pm 15,85$ ve 36. ayda ise $\% 85,86 \pm 18,16$ olarak bildirilmiştir. 3 yıllık takip sonucuna göre yönlendirilmiş doku rejenerasyonu(YDR) tabanında TKG kullanımının kök kapanmasının sağlanmasında etkili bir yöntem olduğu rapor edilmiştir. Kullanılan tekniğin dezavantajlarını otojen trombosit konsantresi kullanılmasına rağmen YDR işlemi için ilave maliyet gereksiniminin olması ve cerrahi işlemin süresinin uzaması olduğunu belirtmişlerdir. ${ }^{47}$

Shepherd ve arkadaşları ${ }^{48}, 18$ hastada bulunan Miller sınıf I ve II dişeti çekilmelerinin tedavisinde ADMA+TZP+kuronale kaydırılan tünel tekniği veya ADMA+kuronale kaydırılan tünel tekniği kullanarak 4. ay sonuçlarını değerlendirmişlerdir. ADMA grubunda ortalama $0,4 \pm 0,5 \mathrm{~mm}, \mathrm{ADMA}+\mathrm{TZP}$ grubunda ise $0,6 \pm 0,8 \mathrm{~mm}$ KDG artışı anlamlı bulunmuştur ve gruplar arasında önemli farklılık bildirilmemiştir. KDK ölçümünü sulkus tabanı ve mukogingival birleşim yeri(MGBY) olmak üzere 2 bölgeden yapmışlardır. Her iki grup için KDK artışı sulkus tabanında ortalama olarak 0,4 mm, MGBY'de yapılan ölçümlerde ise 0,6 $\mathrm{mm}$ olarak bulunmuştur ve gruplar arasında farklılık bildirilmemiştir. KKY, ADMA+TZP grubunda \%90, sadece ADMA uygulanan grupta \%70 olarak elde edilmiştir. Bu fark istatistiksel anlama ulaşamamıştır. ADMA ile birlikte TZP uygulanmasının tek başına ADMA uygulanmasına göre kök kapanmasını geliştirdiği ancak yapılan karşılaştırmalarda istatistiksel olarak anlamlı bir fark bulunamadığı bildirilmiştir. ${ }^{48}$

Kumar ve Murthy'nin ${ }^{49}$ çalışmalarında bilateral izole Miller sınıf I ve II dişeti çekilmelerinin tedavisinde TKG+KKF veya SBDG+KKF kullanılmıştır. 12 aylık takibin sonunda ortalama KKY, SBDG ve TKG uygulanan bölgelerde $\% 83 \pm 14,5$ ve $\% 77 \pm 18,42$ olarak gösterilmiş ve aradaki fark önemli bulunmamıştır. TKG uygulanan bölgelerde KKY 6. ve 12. ayda \%86 17,29 'den $\% 77 \pm 18,42$ 'e gerilemiş ve bu fark önemli olarak kayıt edilmiştir. SBDG'de elde edilen $\mathrm{KKY}$ ise 12 . ayda korunmuştur $(\% 85 \pm 15,23 \text { ve } \% 83 \pm 14,5)^{48}$. Operasyon sonrası 1 . hafta hasta rahatı ile doku renginin ve kalınlığının çevre dokularla olan uyumunun TKG uygulaması sonrası, anlamlı olarak SBDG'den daha iyi olduğu rapor edilmiştir. Operasyon sonrası hasta rahatının artması, cerrahi işlemin süresinin kısalması, daha iyi estetik ve daha az manuel uğraşı gerektirmesi açısından TKG'nin avantajlı olduğu bildirilmiştir. ${ }^{49}$

Trombositten Zengin Fibrin: Aroca ve arkadaşlarının $^{50}$ çalışmalarında yan yana 3 dişte ve aynı çene üzerinde bilateral olarak bulunan benzer Miller sınıf I ve II çoklu dişeti çekilmesi defektleri modifiye kuronale kaydırılan flep(MKKF)+TZF (test grubu), MKKF (kontrol grubu) olacak şekilde tedavi edilmiştir. Test grubunda başlangıca göre 6. ayda görülen kalınlık artışı $(1,4 \pm 0,5)$, kontrol grubuna göre $(1,1 \pm 0,3)$ anlamlı bulunmuştur. Çalışmada test ve kontrol gruplarında başlangıca göre $\mathrm{KDG}^{\prime}$ de görülen azalma ise anlamlı olarak görülürken gruplar arasında anlamlı fark bulunmamıştır. Kontrol grubunda 6. ayda görülen KAS kazancı test grubuna göre anlamlı olarak daha fazladır. Ortalama KKY ve TKK test grubunda 6. ayda sırasıyla $\% 80,7 \pm 14,7$ ve $\% 52,23$, kontrol grubunda ise 6 . ayda $\% 91,5 \pm 11,4$ ve $\% 74,62$ olarak rapor edil- miştir. Çalışmanın sonucunda, TZF'nin MKKF tekniğine ilave olarak kullanılmasının çoklu dişeti çekilmelerinin tedavisinde kök kapanması açısından ek bir yarar sağlamadığı fakat keratinize marjinal dişetinin kalınlığının arttırımasında kullanılmasının faydalı olabileceği bildirilmiştir. ${ }^{50}$

Uraz ve arkadaşları ${ }^{51}$ çoklu dişeti çekilmelerinin tedavisinde TZF+MKKF(test) ve SBDG+MKKF(kontrol) tekniklerini 6 aylık takipte karşılaştırmışlardır. Her iki grup için 6.ayda anlamlı kök kapanması sağlandığı, ÇD ve KAS'da önemli azalma olduğunu ve bununla birlikte KDG'de de artış sağlandığı bildirilmiştir. Ancak gruplar arasında anlamlı fark bildirilmemiştir. Test ve kontrol grubu için ortalama KKY \%95 ve \%96,1 olarak elde edilmiştir. SBDG+MKKF tekniğinde KKY, ÇD'nin 4 mm'den fazla olduğu bölgelerde \%100, 4 mm'den az olduğu bölgelerde ise 93,5, TZF+MKKF tekniğinde ÇD'nin 4 mm'den fazla olduğu bölgelerde \%75, 4 mm'den az olduğu bölgelerde ise \%59,2 olarak kayıt edilmiştir. Buna göre TZF'nin sığ defektlere göre derin defektlerin tedavisinde kök kapanması için daha öngörülebilir sonuç verdiği bildirilmiştir. Çoklu dişeti çekilmelerinin tedavisinde TZF başarılı olarak rapor edilmiş ve daha geniş hasta popülasyonlarında daha uzun takip dönemine sahip çalışmaların yapılması gerektiği belirtilmiştir. ${ }^{51}$

Jankovic ve arkadaşları ${ }^{52}$, 15 hastada bilateral tekli veya çoklu Miller sınıf I ve II dişeti çekilmelerinin tedavisinde TZF+KKF tekniği ile SBDG+ KKF tekniğini kullanarak 12 aylık takip süresi için karşılaştırmışlardır. 6. ayın sonunda KDG artışı SBDG grubunda $(1,44 \pm$ $0,63 \mathrm{~mm})$ TZF grubuna(0,88 $\pm 0,71 \mathrm{~mm})$ göre daha anlamlı bulunmuştur. KKY, TZF için \%88,68ะ10,65, SBDG için ise $\% 91,96 \pm 15,46$ olarak rapor edilmiştir. 
Landry iyileşme indeksi kullanılarak yapılan değerlendirmede 1 . ve 2. haftalarda TZF, SBDG'den anlamlı olarak daha iyi bir iyileşme gösterirken 3. haftada her iki grupta da benzer iyileşme olduğu görülmüştür. VAS skorlarının değerlendirilmesinde TZF grubunda 1 hasta, SBDG grubunda ise 7 hasta için şiddetli ağrı skorları kaydedilmiştir. Operasyon sonrasındaki ilk 7 gün için tüm hastalarda SBDG grubunda TZF'ye göre daha yüksek ağrı skorları kaydedilmiş ve TZF grubunda operasyon sonrası konforun daha iyi olduğu bildirilmiştir. TZF uygulanan bölgelerde, diğer bölgelere göre operasyon sonrası görülen hasta rahatsızıı̆ının azaldığı ve doku iyileşmesinin hızlandığı rapor edilmiştir. ${ }^{52}$

Jankovic ve arkadaşlar $^{53}$, Miller sınıf I ve II dişeti çekilmelerinin tedavisinde TZF+KKF tekniğini ile EMD+KKF tekniği ile 12 aylık dönemde karşılaştırmışlardır. 12 ayın sonunda, TZF grubunda 0,17 $\pm 0,28 \mathrm{~mm}$, EMD grubunda ise $0,60 \pm 0,41 \mathrm{~mm}$ KDG artışı kayıt edilmiştir. KDG artışının anlamlı bulunmasa da EMD grubunda daha fazla olduğu bildirilmiştir. 12. ayda TZF

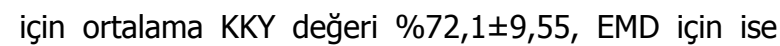
$\% 70,5 \pm 11,76$ olarak rapor edilmiş ve anlamlı farklılık göstermemiştir. Operasyon sonrası ilk 7 gün için yapılan ağrı değerlendirilmesinde EMD grubunda 3 hastanın, TZF grubunda ise 1 hastanın ciddi ağrı şikayeti olduğu bildirilmiştir. İlk 5 günlük değerlendirmede TZF grubunda anlamlı olarak daha düşük skorlar kaydedilirken sonraki 2 günde EMD grubu ile benzer ağrı skorları kayıt edilmiştir. TZF grubunun 1 . hafta sonunda EMD'ye göre anlamlı olarak daha iyi bir iyileşme gösterdiği ve 2 . hafta sonunda ise benzer iyileşme gösterdikleri rapor edilmiştir. TZF'nin cerrahi işlem sonrasında iyileşmeyi EMD'ye göre daha fazla hızlandırmasından dolayı hasta rahatında ilk hafta daha fazla artış sağladığını ve ağrıyı azalttığını, her iki tekniğin de dişeti çekilmelerinin tedavisinde başarılı olduğunu, TZF membranların greft materyali olarak kullanılmasının erken dönem yara iyileşmesini sağladığını ve hasta rahatı açısından avantajları olduğunu bildirmişlerdir. EMD, KDG'nin arttırılmasında TZF'den daha başarılı bulunmuştur. Ayrıca, TZF'nin EMD'e göre kök kapanmasının sağlanmasında üstünlük göstermediği bildirilmiştir. ${ }^{53}$

Padma ve arkadaşlarının ${ }^{54}$ çalışmalarında, 15 hastada bilateral olarak bulunan tekli Miller sınıf I ve II dişeti çekilmeleri, kontrol grubunda sadece KKF ile test grubunda ise KKF+TZF ile tedavi edilmiştir. 6. ayda
TZF+KKF'de görülen KAS'daki azalmanın, KKF'den anlamlı olarak daha fazla olduğu bildirilmiştir. 1., 3. ve 6. aylarda KKY, TZF için $\% 34,58, \% 70,73$ ve $\% 100$, KKF grubunda ise $\% 31,5, \% 61,46, \% 68,44$ olarak rapor edilmiştir. 6. ay için yapılan karşılaştırmada TZF grubu için anlamlı farklılık gösterilmiştir. KDG artışı TZF+KKF grubunda, KKF grubuna göre 1., 3. ve 6 . aylarda anlamlı olarak daha fazla artış göstermiştir. Miller sınıf I veya II dişeti çekilmesi defektlerinin tedavisinde KKF tekniğine ilave olarak TZF uygulanmasının, 6 ay sonunda KKY ve KDG'nin arttırılmasında ve aynı zamanda KAS'da azalmanın elde edilmesinde ek yarar sağladığını bildirilmiştir. ${ }^{54}$

Eren ve Atilla'nın ${ }^{43}$ yaptıkları çalışmada, aynı hastada yer alan simetrik ve tekli olarak bulunan Miller sınıf I ve II dişeti çekilmelerinin tedavisinde, TZF+KKF tekniği ile SBDG+KKF tekniği 6 aylık takip süresi için klinik olarak karşılaştırılmıştır. KDG, TZF grubunda başlangıçta $2.58 \pm 1.37 \mathrm{~mm}, 6$. ayda $3.51 \pm 1.28$, SBDG grubunda ise başlangıçta $2.41 \pm 1.20 \mathrm{~mm}, 6$. ayda ise $3.63 \pm 1.43 \mathrm{~mm}$ olarak artış göstermiş ve gruplar arasında anlamlı farklılık bildirilmemiştir. TZF için ortalama KDK değerleri $\pm 0.18 \mathrm{~mm}$ 'den, 6. ayda $1.59 \pm 0.53 \mathrm{~mm}$ 'e, SBDG grubunda ise $\pm 0.23 \mathrm{~mm}$ 'den, 6. ayda $1.68 \pm 0.57 \mathrm{~mm}$ 'e artış göstermiş ve aralarında fark bulunmamıştır. Ortalama KKY değerleri, 6. ayın sonunda TZF grubunda \%92,7 ve SBDG grubunda \%94,2 olarak bildirilmiştir. Çalışmanın sınırları içerisinde olmak üzere tekli dişeti çekilmelerinin tedavisinde, TZF+KKF tekniğinin SBDG+KKF tekniğine benzer sonuçlar verdiği ve izole dişeti çekilmelerinin tedavisinde alternatif olabileceği bildirilmiştir. ${ }^{43}$

Tunalı ve arkadaşları ${ }^{55}$, bilateral çoklu Miller sınıf I ve II dişeti çekilmesi defektlerinin tedavilerinde TZF+KKF veya SBDG+KKF tekniklerini kullanarak karşılaştırmışlardır. 10 hastada yer alan toplam 44 defekt tedavi edilmiştir. 12 aylık takibin sonunda ortalama KKY, TZF ve SBDG için \%76,63 ve \%77,36 olarak bildirilmiştir. KAS kazancı(2,90 mm ve 3,04 mm) ve $\mathrm{KDG}^{\prime}$ deki artış $(0,6 \mathrm{~mm})$ her iki grup için de anlamlıdır ancak aralarında önemli fark bulunmamıştır. TZF'nin 3 mm'den daha büyük ÇD'ye sahip çoklu dişeti çekilmelerinin tedavilerinde SBDG'ye alternatif olarak kullanılabileceği bildirilmiştir. ${ }^{55}$

Keçeli ve arkadaşlarını ${ }^{56}$ çalışmalarında, 40 hastada anterior veya premolar bölgede bulunan ÇD $\geq$ $3 \mathrm{~mm}$ olan izole Miller sınıf I veya II dişeti çekilmesi defektleri, TZF+SBDG+KKF(test) ya da SBDG+KKF 
(kontrol) ile tedavi edilerek sonuçları klinik olarak karşılaştırıımıştır. Çalışmada 6 ay sonunda ortalama KKY ve tam kök kapanması, test grubu için \%89,6 ve $\% 55$ iken kontrol grubunda $\% 79,6$ ve \%35 olarak rapor edilmiş ve test grubunda anlamlı olarak daha yüksek olduğu bildirilmiştir. KAS kazancının TZF uygulanan grupta 3,10 $\pm 080 \mathrm{~mm}(\% 69)$, kontrol

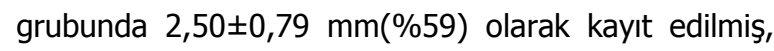
TZF için ataşman kazancının aradaki fark az da olsa anlamlı olarak daha fazla olduğu bildirilmiştir. Bununla birlikte test ve kontrol grupları için anlamlı görülen keratinize doku kazancındaki artış sırasıyla ortalama olarak $1,23 \pm 0,67 \mathrm{~mm}(\% 25,9)$ ve $0,83 \pm 0,55 \mathrm{~mm}$ $(\% 21,5)$ olarak bildirilmiş gruplar arasında istatistiksel anlamda fark gösterilmemiştir. KDK'da 3. ve 6. aylarda görülen artış TZF grubunda, kontrol grubuna göre anlamlı olarak daha fazladır. Çalışmanın sonucuna göre TZF SBDG+KKF ile elde edilen primer sonuçları KDK'yi arttırmak dışında geliştirmemiştir. ${ }^{56}$

Konsantre Büyüme Faktörü: Doğan ve ark ${ }^{57}$. çalışmalarında, çoklu dişeti çekilmelerinin tedavisinde KKF işlemi üzerine KBF'nin etkinliği klinik olarak değerlendirilmiştir. 6. ayın sonunda ortalama KKY ve tam kök kapanması, sadece KKF uygulanan bölgelerde $\% 82,6$ ve \%45,8(27/59) ve KKF+KBF için \%86,67 ve $\% 56,7(34 / 60)$ olarak rapor edilmiştir. KBF'nin KKF uygulamalarında KKY üzerine ek bir yarar sağlamadığı ancak KDG ve KDK için anlamlı olarak daha fazla artış sağladığı tespit edilmiştir. KKF cerrahisi sonrasında görülen geri dönüşlerin azaltılması ve elde edilen kök kapanmasının uzun dönem sürdürülmesinde KBF ile elde edilen dişeti genişliği ve kalınlığı artışının fayda sağlayabileceği bildirilmiştir.

\section{TARTIŞMA}

Trombosit konsantrelerinin tedavi amacı ile kullanılması temel olarak büyüme faktörleri ile hücre terapisinin yapılması tabanına dayanmaktadır. ${ }^{13}$ Kullanılan santrifüj sistemleri ve elde edilme aşamaları sonuç olarak elde edilen trombosit konsantresinin fibrin ağ yapısını ve mekanik özelliklerini değiştirmektedir. TZP ve fibrin adezivlerde koagülasyonun son aşamasında hızı fibrin polimerizasyonunu sağlamak için sığır trombini ve kalsiyum klorid kullanılmaktadır. TZP ve fibrin adezivlerinde görülen hızlı polimerizasyon süreci ve yüksek trombin konsantrasyonu, fibrin matriks sitokinlerinin iletişimlerini ve hareketlerini güçleştiren, bununla birlikte sitokin tutulumu ile hücre migrasyonunun zorlaştığı rijit bir fibrin ağ yapısı oluşumuna neden olur.1,13 TZF tamamen otolog olmasına ilave olarak trombosit ve lökositten zengin fibrin biyomateryali olarak tanımlanmaktadır., 43,16 TZF'nin TZP'ye göre avantajları; hazırlanmasının daha kısa zaman alması, sığır trombini veya antikoagülan kullanımının gerekmemesi, daha yoğun bir fibrin ağ yapısı içermesi ve uygulanmasının kolaylığı olarak sıralanmaktadır. ${ }^{43}$ TZF'de görülen yavaş polimerizasyon ve az trombin konsantrasyonu, hücre göçü ve çözünebilir moleküllerin tutulmasını destekleyen oldukça elastik bir fibrin ağı oluşumunu sağlamaktadır. ${ }^{1}$ Antikoagülan kullanılmaması, doğal ve yavaş gelişen polimerizasyon süreci TZF'yi manipülasyonu kolay bir biyomateryal haline getirmektedir ve TZF 2 sert yüzey arasında sıkıştırılarak membran halinde de kullanılabilmektedir. ${ }^{58-60 .}$ TZF fibrin ağ yapısı içerisinde bulunan yüksek oranda büyüme faktörü ve diğer matriks glikoproteinlerini yaklaşık olarak 7 gün boyunca serbest bırakmaktadır. ${ }^{60}$ TZF'de ki bu biyokimyasal bileşenler ve fibrin yapısı, yara iyileşmesini ve doku rejenerasyonunu desteklemektedir. ${ }^{16}$

TZP dişeti çekilmelerinin kapatılması amacıyla kullanıldığı çalışmalarda tek başına ${ }^{46}$, SBDG ile birlikte ${ }^{44,45}$ TKG $^{6,47}$ olarak ya da ADMA ${ }^{48}$ ile birlikte açık kök yüzeyi üzerine uygulanmıştır ve üzeri KKF ile örtülmüştür. TZP'nin TKG olarak uygulanmasının, SBDG ile benzer KKY ve KDG artışı sağladığı ve estetiği geliştirdiği bildirilmiştir. ${ }^{6,49}$ SBDG ile birlikte kullanıldığı iki ayrı çalışmada ise farklı iki sonuç bulunmaktadır. Jankovic ve arkadaşları ${ }^{44}$ TZP'nin SBDG'ye ilave olarak kullanılmasının doku iyileşmesini hızlandırdığı, KDG'de daha fazla kazanç sağladığını, operasyon sonrası ağrıda azalma ile hasta konforunu arttırdığını ve benzer kök kapanması görüldüğünü rapor ederken Keçeli ve arkadaşları ${ }^{45}$ sadece klinik değerlendirme yaptıkları çalışmalarında KDG artışında fark bildirmezken, TZP'nin KKY, KAS kazancını da geliştirmediğini ayrıca manipülasyonu zor bir materyal olduğunu bildirmişlerdir. Farklı çalışmalarda, TZP'nin KKF ile birlikte ya da ADMA ile birlikte kullanılmasının KDK'da ilave artış sağlamadığı da gösterilmiştir. ${ }^{46,48}$ Ancak, çalışma tasarımları ve dahil edilen çekilme defektlerinin(tekli ve çoklu) farklı olması veya TZP elde edilmesinde kullanılan sistemlerin farklı olması klinik sonuçları etkileyebilmektedir. Çalışmalarda kullanılan santrifüj sistemleri, dolayısıyla trombosit sayıları ve 
büyüme faktörü miktarları da birbirinden farklılık göstermektedir. Ayrıca Keçeli ve arkadaşlarının ${ }^{45}$ yaptığı çalışmada TZP'nin içerisindeki trombosit miktarının ve büyüme faktörlerinin artışı ile KAS kazancı ve KKY arasında bir ilişki olmadığı korelasyon analizleriyle de gösterilmiştir.

TZF çalışmalarda, KKF veya MKKF ile birlikte kullanılarak, sadece KKF ${ }^{50,54}$, SBDG+KKF ${ }^{43,51,52,55}$ ile veya $\mathrm{EMD}+\mathrm{KKF}^{53}$ ile klinik veya hasta tabanlı parametreler yardımıyla karşılaştırılmıştır. Çoklu dişeti çekilmelerinin tedavisinde Uraz ve $\operatorname{arkadaşları~}{ }^{51}$, $4 \mathrm{~mm}$ 'den daha derin olan defektlerde, sığ defektlerde kullanılmasına göre daha başarılı olduğunu ve SBDG' ye benzer KKY ve KDG artışı elde edildiğini bildirirken Tunalı ve arkadaşları ${ }^{55} 3 \mathrm{~mm}^{\prime}$ den derin defektlerde SBDG'ye alternatif olabileceğini rapor etmişlerdir. Aroca ve arkadaşları ${ }^{50}$ çoklu çekilmelerde MKKF ile ilave kullanımının KKY üzerine fark yaratmadığını sadece marjinal dişeti kalınlığında artış sağladığını bildirmişlerdir. İzole dişeti çekilmelerinin tedavisinde, Padma ve ark. ${ }^{54}$ KKF tekniğine ilave olarak kullanılmasının KKY ve KDG'de artış sağladığını, Eren ve Atilla ${ }^{43}$ ise SBDG ile karşılaştırıldığında benzer KKY, KDG ve KDK artışı elde edildiğini ve alternatif olabileceğini bildirmişlerdir. İyileşme ve hasta konforunun değerlendirildiği iki çalışmada SBDG ve EMD uygulamasına göre operasyon sonrası ağrının anlamlı olarak daha az görüldüğü ve iyileşmenin erken dönemde hızlandığı bildirilmiştir. ${ }^{52,53}$ Keçeli ve arkadaşları KKF ile birlikte TZF+SBDG uygulaması ile $3 \mathrm{~mm}$ 'den büyük defekt derinliğindeki izole çekilmelerde, SBDG'ye göre daha yüksek kök kapanması elde edildiğini, bununla birlikte ataşman kazancı ve kalınlık artışında da anlamlı olarak artış sağlandığını rapor etmişlerdir. ${ }^{56}$

SBDG ile birlikte trombosit konsantrelerinin uygulanması, araştırmacılar tarafından literatürde farklı şekillerde yapılmaktadır. Greft trombosit jeli(TZP) ile kaplanarak kök yüzeyine uygulanmış ${ }^{45}$ ya da açık kök yüzeyi ve komşu periosta veya alveolar kemiğe önce TZF uygulanarak sonra üzerine SBDG yerleştirilmiştir. ${ }^{56}$ Konuyla ilgili olarak uygulamanın şeklinin rejenerasyonu tam olarak nasıl etkilediğini gelecekte yapılacak histolojik çalışmaların ortaya koyabileceği belirtilmiştir. $^{56}$ SBDG+TZF benzer çalışma dizaynında, SBDG+ TZP'ye göre klinik sonuçlar açısından daha başarılı görünmektedir. TZP'de kısa dönem ve kontrolsüz büyüme faktörü salınım kinetiğinin varlığına karşılık, TZF'de görülen 3 boyutlu fibrin ağ yapısının sahip olduğu büyüme faktörlerini proteolitik yıkımdan koruması $^{61}$, TZF ile yapılan çalışmalardaki başarının nedenini açıklayabilir. ${ }^{62}$

Yapılan çalışmalarda TZF ve TZP kullanılması sonucunda KDG'de artış sağlanmasının, salınan büyüme faktörlerinin etkisi sonucu gingival veya periodontal fibroblastların proliferasyonunun uyarılması ve dokunun yönlendirilmesi ile ilişkili olduğu düşünülmüştür. Bununla birlikte SBDG'de ise bu artışın nedeninin bağ dokusunun epitel keratinizasyonunu uyarma yeteneğine sahip olması sonucunda gerçekleştiği bildirilmiştir. 6,43,44,52 TZF'nin KDK'yı arttırması ile ilgili olarak aynı mekanizma belirtilmiştir ve bununla birlikte membran görevi görerek aralık oluşturmasının da etkili olabileceği düşünülmüştür. ${ }^{56}$

Çalışmalarda KDK ölçüm yerleri ve yöntemleri de değişiklik göstermektedir. Huang ve arkadaşları ${ }^{46}$, dişeti marjininden $2 \mathrm{~mm}$ uzakta olacak şekilde ve periodontal sond yardımı ile Aroca ve arkadaşları ${ }^{50}$, dişeti marjininden $3 \mathrm{~mm}$ uzakta 15 no'lu endodontik eğe ve kumpas yardımı ile Shepherd ve arkadaşları ${ }^{48}$, ultrasonik ölçüm cihazı ile (ölçüm yeri belirtilmemiş), Eren ve Atilla ${ }^{43}$ lokal anestezi altında dişeti marjininden $2 \mathrm{~mm}$ uzakta endodontik eğe ve kumpas yardımıyla KDK değerlerini belirlemişlerdir. Buna göre, ölçüm yerlerindeki farklılıklar alınan sonuçlarda değişimlere neden olmuş olabilir.

TZF elde edilmesinde kullanılan tüplerin özellikleri ve cam tüplerin veya silika kaplı plastik tüplerin kullanılmasının ya da membran elde etmek için pıhtıya uygulanan kompresyonun (güç uygulanarak ya da uygulanmadan) elde edilen TZF'nin içeriği üzerine etkili olabileceği düşünülmektedir. ${ }^{16} \mathrm{Bu}$ amaçla yapılan çalışmanın analiz sonuçlarına göre, TZF'nin üç boyutlu yapısının değişmediği ancak bu iki parametrenin büyüme faktörü içeriğini ve sonuç olarak elde edilen membranda matriks yapısının özelliklerini etkileyebileceği bildirilmiştir. ${ }^{16}$ Bu nedenle, TZF protokolünün standart hale getirilmesi için özel bir metal kutu "PRF box (Process, Nice, France)" tasarlanmıştır. ${ }^{58}$ Santrifüj sonrası elde edilen TZF metal kutunun içine yerleştirilerek membran haline getirilebilmektedir. TZF ıslak ve steril bir çevrede kullanılıncaya kadar daha uzun süre bekleyebilmektedir. Bu metot ile TZF ağ yapısında bulunan trombosit kaynaklı büyüme faktörlerinin kaybının önleneceği bununla beraber kompresyonun yavaş ve nazik olması ile zarar görmelerinin de önleneceği bildirilmiştir. ${ }^{58}$ 
TZF'nin elde edilme şekli, elde edildikten sonra korunma şartları ve yara bölgesine uygulanma protokolü de çalışma sonuçlarını etkileyebilir. Aroca ve arkadaşlarının $^{50}$ çalışmasında TZF membran, flep marjiniyle aynı sınırda olacak şekilde $0,5 \mathrm{~mm}$ kalınlı̆ında (tek tabaka) olarak uygulanmışır. Ayrıca elde edilen TZF, kullanılıncaya kadar buzdolabında muhafaza edilmiştir. Çalışmadaki uygulamayla ilgili olarak editöre yazılan mektupta ${ }^{63}$ TZF membranın elde edildikten sonra bilinmeyen bir süre buzdolabında kuru gazlı bez içinde saklanmasının membranda dehidratasyona ve büzülmeye neden olacağı, büyüme faktörü içeriğinin değişeceğ ${ }^{64}{ }^{6}$ ve steril bir çevrenin sağlanamayacağı vurgulanmıştır. ${ }^{63} \mathrm{TZF}^{\prime}$ nin periodontal cerrahilerde kullanımı ile ilgili olarak vaskülarizasyonun çok etkili olduğu gingival çevrede fibrin yapının hızlıca rezorbe olmasından dolayı TZF membranların en az 2, olabiliyorsa 3 kat halinde uygulanmalarının gerektiği belirtilmiştir. ${ }^{63,65,66}$ TZF membranlar homojen olmayan bir yapı göstermektedir ve bu yapı içerisinde lökosit ile trombosit kaynaklı büyüme faktörleri membranın sonunda lokalize olmaktadır. ${ }^{1}$ Bu nedenle iki kat TZF membranın birbirine zıt yönde yerleştirilmesi ile TZF içindeki bileşenlerin cerrahi bölgesinde eşit derecede etkinlik sağlayacağı düşünülmektedir. ${ }^{63}$ TZF membranların dişeti sıııının hafifçe kuronaline yerleştirilmesi ile kök yüzeyi ile dişeti arasında iyileşme için bir boşluk oluşturulabildiği hem de dişetinin kök yüzeyinden ayrılmasının sağlandığı bildirilmiştir. ${ }^{63} \quad$ TZF'nin $^{\prime}$ iyileşmeyi, gingival bağ dokusunu üzerinde bulunan büyüme faktörleriyle ve kök yüzeyini hücre migrasyonu için anahtar proteinlerle (fibronektin, vitronektin, trombospondin-1) stimüle ederek sağladığı düşünülmektedir. TZF'nin adheziv özelliklerinin stabil bir flep pozisyonu elde edilmesine, damarlanmanın arttırımasına, flep nekrozunun azalmasına ve kök kapanmasının en iyi şekilde elde edilmesine olumlu katkı yapabileceği belirtilmiştir. ${ }^{63}$

Choukroun'un TZF protokolü için tanımlanan orijinal protokole uymadan elde edilen TZF-benzeri pıhtı yapılarının lökosit ve trombosit konsantrasyonlarının yetersiz olabileceği, büyüme faktörlerinin fibrin yapısı içindeki tutulumlarının da tehlikeye düşebileceği rapor edilmiştir. ${ }^{16,64} \mathrm{Bu}$ durumun klinik sonuçlarda değişikliklere yol açabileceği de belirtilmiştir. ${ }^{16,63}$

Trombosit konsantrelerinin dişeti çekilmelerinin tedavisinde kullanıldığı çalışmalarda kullanılan cerrahi teknik, TZP ve TZF elde etme yöntemleri ve uygulama şekilleri, operasyon sonrası hastalara önerilen ilaç ejimleri, değerlendirilen parametreler ve takip süreleri açısından önemli farklılıklar bulunmaktadır. Bu durum çalışmalarda elde edilen sonuçlarda değişikliklerin olmasına yol açmış olabilir. TZF, TZP'ye göre KKY, KDG, KDK parametreleri göz önünde bulundurulduğunda daha başarılı görünmektedir. Sezgin ve Taner de derlemelerinde TZF'nin diş ve implant ile ilgili yumuşak ve sert dokuyu içeren cerrahi uygulamalar için umut verici bir biyomateryal olduğunu bildirmişlerdir. ${ }^{67} \mathrm{KBF}^{\prime}$ nin çoklu dişeti çekilmelerinin tedavisinde KKF uygulamalarının sonucunu anlamlı olarak geliştirdiği rapor edilmiştir. ${ }^{57}$ A-PRF ve T-TZF'nin tedavi amacıyla kullanıldığı çalışmalar henüz literatürde bulunmamaktadır. Dişeti çekilmelerinin tedavisinde tüm bu biyomateryallerin klinik olarak karşılaştırıldığı, hasta rahatı ile iyileşmeye olan etkilerinin değerlendirildiği ileri çalışmalar gerekmektedir. Bu otojen biyomateryallerin rejeneratif potansiyellerinin aydınlatıması için histolojik çalışmalara da ihtiyaç bulunmaktadır.

\section{TEŞEKKÜR}

Bu derleme Gazi Üniversitesi Bilimsel Araştırma Projeleri birimi tarafindan 03/2011-16 kodlu proje ile desteklenmiş̧ir.

\section{KAYNAKLAR}

1. Dohan DM, Choukroun J, Diss A, Dohan SL, Dohan AJ, Mouhyi J, Gogly B. Platelet-rich fibrin (PRF): a second-generation platelet concentrate. Part II: platelet-related biologic features. Oral Surg Oral Med Oral Pathol Oral Radiol Endod 2006; 101:e4550.

2. Rozman P, Bolta Z. Use of platelet growth factors in treating wounds and soft-tissue injuries. Acta dermatovenerol Alp Panonica Adriat 2007; 16:15665.

3. Anitua E, Andia I, Ardanza B, Nurden P, Nurden AT. Autologous platelets as a source of proteins for healing and tissue regeneration. Thromb Haemost 2004; 91:4-15.

4. Dohan Ehrenfest DM, Rasmusson L, Albrektsson T. Classification of platelet concentrates: from pure platelet-rich plasma (P-PRP) to leucocyte- and platelet-rich fibrin (L-PRF). Trends Biotechnol 2009; 27:158-67. 
5. Soffer E, Ouhayoun JP, Anagnostou F. Fibrin sealants and platelet preparations in bone and periodontal healing. Oral Surg Oral Med Oral Pathol Oral Radiol Endod 2003; 95:521-8.

6. Cheung WS, Griffin TJ. A comparative study of root coverage with connective tissue and platelet concentrate grafts: 8-month results. ] Periodontol 2004; 75:1678-87.

7. Marx RE, Carlson ER, Eichstaedt RM, Schimmele SR, Strauss JE, Georgeff KR. Platelet-rich plasma: Growth factor enhancement for bone grafts. Oral Surg Oral Med Oral Pathol Oral Radiol Endod 1998; 85:638-46.

8. Tozum TF, Demiralp B. Platelet-rich plasma: a promising innovation in dentistry. J Can Dent Assoc 2003; 69:664.

9. Choukroun J, Diss A, Simonpieri A, Girard MO, Schoeffler C, Dohan SL, Dohan AJ, Mouhyi J, Dohan DM. Platelet-rich fibrin (PRF): a secondgeneration platelet concentrate. Part V: histologic evaluations of PRF effects on bone allograft maturation in sinus lift. Oral Surg Oral Med Oral Pathol Oral Radiol Endod 2006; 101:299-303.

10. Del Fabbro M, Bortolin M, Taschieri S, Weinstein R. Is platelet concentrate advantageous for the surgical treatment of periodontal diseases?A systematic review and meta-analysis. J Periodontol 2011; 82:1100-11.

11. Del Corso $M$, Vervelle $A$, Simonpieri $A$, Jimbo $R$, Inchingolo $F$, Sammartino $G$, and Dohan Ehrenfest DM. Current knowledge and perspectives for the use of platelet-rich plasma (PRP) and platelet-rich fibrin (PRF) in oral and maxillofacial surgery part 1: Periodontal and dentoalveolar surgery. Curr Pharm Biotechnol. 2012; 13:1207-30.

12. Simonpieri $A$, Del Corso $M$, Vervelle $A$, Jimbo $R$, Inchingolo $F$, Sammartino G, Dohan Ehrenfest DM. Current knowledge and perspectives for the use of platelet-rich plasma (PRP) and platelet-rich fibrin (PRF) in oral and maxillofacial surgery part 2: Bone graft, implant and reconstructive surgery. Curr Pharm Biotechnol. 2012; 13:1231-56.

13. Dohan DM, Choukroun J, Diss A, Dohan SL, Dohan AJ, Mouhyi J, Gogly B. Platelet-rich fibrin (PRF): a second-generation platelet concentrate. Part I: technological concepts and evolution. Oral Surg
Oral Med Oral Pathol Oral Radiol Endod 2006;101:37-44.

14. Dohan DM, Choukroun J, Diss A, Dohan SL, Dohan AJ, Mouhyi J, Gogly B. Platelet-rich fibrin (PRF): a second-generation platelet concentrate. Part III: leucocyte activation: a new feature for platelet concentrates? Oral Surg Oral Med Oral Pathol Oral Radiol Endod 2006; 101:e51-5.

15. Choukroun J, Diss A, Simonpieri A, Girard MO, Schoeffler C, Dohan SL, Dohan AJ, Mouhyi J, Dohan DM. Platelet-rich fibrin (PRF): a secondgeneration platelet concentrate. Part IV: clinical effects on tissue healing. Oral Surg Oral Med Oral Pathol Oral Radiol Endod 2006; 101: e56-60.

16. Dohan Ehrenfest DM, Del Corso M, Diss A, Mouhyi J, Charrier JB. Three-dimensional architecture and cell composition of a Choukroun's platelet-rich fibrin clot and membrane. J Periodontol 2010; 81:546-55.

17. Tunali M, Ozdemir H, Kucukodaci Z, Akman S, Firatli E. In vivo evaluation of titanium-prepared platelet-rich fibrin (T-PRF): a new platelet concentrate. $\mathrm{Br}$ J Oral Maxillofac Surg. 2013; 51:438-43.

18. Tunali M, Ozdemir H, Kucukodaci Z, Akman S, Yaprak E, Toker H, Firatli E. A novel platelet concentrate: titanium-prepared platelet-rich fibrin. Biomed Res Int. 2014; 2014: 209548 (1-7).

19. Ghanaati S, Booms P, Orlowska A, Kubesch A, Lorenz J, Rutkowski J, Landes C, Sader R, Kirkpatrick C, Choukroun J. Advanced plateletrich fibrin: a new concept for cell-based tissue engineering by means of inflammatory cells. J Oral Implantol. 2014; 40: 679-89.

20. Sohn DS. The effect of concentrated growth factors on ridge augmentation. Dental Inc 2009; 34-40.

21. Rodella LF, Favero G, Boninsegna R, Buffoli B, Labanca M, Scari G, Sacco L, Batani T, Rezzani R. Growth factors, CD34 positive cells, and fibrin network analysis in concentrated growth factors fraction. Microsc Res Tech 2011; 74:772-7.

22. Yu B, Wang Z. Effect of concentrated growth factors on beagle periodontal ligament stem cells in vitro. Mol Med Rep 2014; 9: 235-42.

23. Sohn DS, Heo JU, Kwak DH, Kim DE, Kim JM, Moon JW, Lee JH, Park IS. Bone regeneration in the maxillary sinus using an autologous fibrin-rich

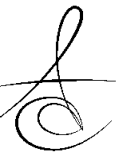


block with concentrated growth factors alone. Implant Dent 2011; 20: 389-95.

24. Sohn D.S, Moon JW, Moon YS, Park JS, Jung HS. The use of concentrated growth factors (CGF) for sinus augmentation. J Oral Implantol 2009; 38:2538.

25. Kim JM, Sohn DS, Bae MS, Moon JW, Lee JH, and Park IS. Flapless transcrestal sinus augmentation using hydrodynamic piezoelectric internal sinus elevation with autologous concentrated growth factors alone. Implant Dent 2014; 23: 168-74.

26. Internet: Corigliano $M$, Sacco $L$, Baldoni $E$, International Academy of Implanto Prosthesis and Osteoconnections the CGF: A Therapeutic Proposal for Regenerative Medicine. URL: www. panoramadentale.it/pdf/CGF.pdf, Son Erişim Tarihi: 08.11.2016.

27. Kim TH, Kim SH, Sandor GK, Kim YD. Comparison of platelet-rich plasma (PRP), platelet-rich fibrin (PRF), and concentrated growth factor (CGF) in rabbit-skull defect healing. Arch Oral Biol 2014; 59: 550-8.

28. Dohan Ehrenfest DM, Bielecki T, Mishra A, Borzini $P$, Inchingolo $F$, Sammartino $G$, Rasmusson $L$, Evert PA. In search of a consensus terminology in the field of platelet concentrates for surgical use: platelet-rich plasma (PRP), platelet-rich fibrin (PRF), fibrin gel polymerization and leukocytes. Curr Pharm Biotechnol. 2012; 13: 1131-7.

29. Dohan Ehrenfest DM, Bielecki T, Jimbo R, Barbe G, Del Corso M, Inchingolo F, Sammartino G. Do the fibrin architecture and leukocyte content influence the growth factor release of platelet concentrates? An evidence-based answer comparing a pure platelet-rich plasma (P-PRP) gel and a leukocyteand platelet-rich fibrin (L-PRF). Curr Pharm Biotechnol. 2012; 13: 1145-52.

30. Internet: Glossary of Periodontal Terms. 4 Edition, Chicago, Periodontology, A.A.O. (2001).URL:http:// www.perio.org/sites/default/files/files/PDFs/Publica tions/GlossaryOfPeriodontalTerms2001Edition.pdf, Son Erişim Tarihi: 08.11.2016.

31. Tugnait A, Clerehugh V. Gingival recession-its significance and management. J Dent 2001; 29: 381-94.

32. Chabanski MB, Gillam DG. Aetiology, prevalence and clinical features of cervical dentine sensitivity. J Oral Rehabil 1997; 24:15-9.
33. Zucchelli G, Amore C, Sforza NM, Montebugnoli L, De Sanctis M. Bilaminar techniques for the treatment of recession-type defects. A comparative clinical study.J Clin Periodontol2003; 30: 862-870.

34. Alkan A, Keskiner I, Yuzbasioglu E. Connective tissue grafting on resin ionomer in localized gingival recession. J Periodontol 2006; 77: 144651.

35. Reiker J, Van der Velden U, Barendregt DS, Loos BG. A cross-sectional study into the prevalence of root caries in periodontal maintenance patients. J Clin Periodontol 1999; 26: 26-32.

36. Zucchelli G, Mounssif I. Periodontal plastic surgery. Periodontol 2000. 2015; 68(1): 333-68.

37. Wennstrom JL. Mucogingival therapy. Ann Periodontol 1996; 1: 671-701.

38. Chambrone L, Chambrone D, Pustiglioni FE, Chambrone LA, Lima LA. Can subepithelial connective tissue grafts be considered the gold standard procedure in the treatment of Miller Class I and II recession-type defects?. J Dent 2008; 36: 659-671.

39. Buti J, Baccini M, Nieri M, La Marca M, Pini-Prato GP. Bayesian network meta-analysis of root coverage procedures: ranking efficacy and identification of best treatment. J Clin Periodontol2013; 40: 372-386.

40. Roccuzzo M, Bunino M, Needleman I, Sanz M. Periodontal plastic surgery for treatment of localized gingival recessions: a systematic review. J Clin Periodontol 2002, 29 Suppl 3: 178-194; discussion 195-176.

41. Chambrone L, Pannuti CM, Tu YK, Chambrone LA. Evidence-based periodontal plastic surgery. II. An individual data meta-analysis for evaluating factors in achieving complete root coverage. J Periodontol 2012; 83: 477-490.

42. Cairo F, Pagliaro U, Nieri M. Treatment of gingival recession with coronally advanced flap procedures: a systematic review. J Clin Periodontol 2008; 35: 136-162.

43. Eren G, Atilla G. Platelet-rich fibrin in the treatment of localized gingival recessions: a split-mouth randomized clinical trial. Clin Oral Investig 2014; 18: 1941-8.

44. Jankovic S.M, Zoran AM, Vojislov LM, Dimitrijevic $S B$, Kenney $B E$. The use of platelet-rich plasma in

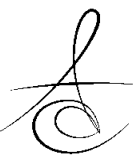


combination with connective tissue grafts following treatment of gingival recessions. Periodontal Pract Today 2007; 4: 63-71.

45. Keceli HG, Sengun D, Berberoglu A, Karabulut E. Use of platelet gel with connective tissue grafts for root coverage: a randomized-controlled trial. J Clin Periodontol 2008; 35: 255-62.

46. Huang L.H, Neiva RE, Soehren S.E, Giannobile WV, Wang H.L.The effect of platelet-rich plasma on the coronally advanced flap root coverage procedure: a pilot human trial. J Periodontol 2005; 76:176877.

47. Griffin TJ, Cheung WS. Guided tissue regenerationbased root coverage with a platelet concentrate graft: a 3-year follow-up case series. J Periodontol 2009; 80: 1192-9.

48. Shepherd N, Greenwell H, Hill M, Vidal R, Scheetz JP. Root Coverage Using Acellular Dermal Matrix and Comparing a Coronally Positioned Tunnel With and Without Platelet-Rich Plasma: A Pilot Study in Humans. J Periodontol 2009; 80: 397-404.

49. Kumar GN, Murthy KR. A comparative evaluation of subepithelial connective tissue graft (SCTG) versus platelet concentrate graft (PCG) in the treatment of gingival recession using coronally advanced flap technique: A 12-month study. J Indian Soc Periodontol. 2013;17: 771-6.

50. Aroca S, Keglevich T, Barbieri B, Gera I, Etienne D. Clinical evaluation of a modified coronally advanced flap alone or in combination with a platelet-rich fibrin membrane for the treatment of adjacent multiple gingival recessions: a 6-month study. J Periodontol 2009; 80: 244-52.

51. Uraz A, Sezgin Y, Yalim M, Taner IL, Çetiner D, Comparative evaluation of platelet-rich fibrin membrane and connective tissue graft in the treatment of multiple adjacent recession defects: A clinical study. J Dent Sci 2015;10:36-45

52. Jankovic S, Aleksic Z, Klokkevold P, Lekovic V, Dimitrijevic B, Kenney EB, Camargo P. Use of platelet-rich fibrin membrane following treatment of gingival recession: a randomized clinical trial. Int J Periodontics Restorative Dent. 2012; 32: 4150.

53. Jankovic S, Aleksic Z, Milinkovic I, Dimitrijevic B. The coronally advanced flap in combination with platelet-rich fibrin (PRF) and enamel matrix derivative in the treatment of gingival recession: a comparative study. Eur J Esthet Dent. 2010;5:26073.

54. Padma R, Shilpa A, Kumar PA, Nagasri M, Kumar C, Sreedhar A. A split mouth randomized controlled study to evaluate the adjunctive effect of plateletrich fibrin to coronally advanced flap in Miller's class-I and II recession defects. J Indian Soc Periodontol 2013; 17: 631-6.

55. Tunalı M, Özdemir H, Arabacl T, Gürbüzer B, Pikdöken L, Firatli E. Clinical evaluation of autologous platelet-rich fibrin in the treatment of multiple adjacent gingivalrecession defects: a 12-month study. Int J Periodontics Restorative Dent. 2015; 35: 105-14.

56. Keceli HG, Kamak G, Erdemir EO, Evginer MS, Dolgun A. The Adjunctive Effect of PlateletRich Fibrin to Connective Tissue Graft in the Treatment of Buccal Recession Defects: Results of a Randomized, Parallel-Group Controlled Trial. J Periodontol. 2015; 86: 1221-30.

57. Doğan ŞB, Dede FÖ, Ballı U, Atalay EN, Durmuşlar MC. Concentrated growth factor in the treatment of adjacent multiple gingival recessions: a splitmouth randomized clinical trial. J Clin Periodontol. 2015; 42: 868-75.

58. Dohan Ehrenfest, DM. How to optimize the preparation of leukocyte- and platelet-rich fibrin (L-PRF, Choukroun's technique) clots and membranes: introducing the PRF Box. Oral Surg Oral Med Oral Pathol Oral Radiol Endod 2010; 110: 275-278; author reply 278-80.

59. Su CY, Kuo YP, Tseng YH, Su CH, Burnouf T. In vitro release of growth factors from platelet-rich fibrin (PRF): a proposal to optimize the clinical applications of PRF. Oral Surg Oral Med Oral Pathol Oral Radiol Endod 2009; 108: 56-61.

60. Dohan Ehrenfest DM, Diss A, Odin G, Doglioli P, Hippolyte MP, Charrier JB. In vitro effects of Choukroun's PRF (platelet-rich fibrin) on human gingival fibroblasts, dermal prekeratinocytes, preadipocytes, and maxillofacial osteoblasts in primary cultures. Oral Surg Oral Med Oral Pathol Oral Radiol Endod 2009; 108: 341-52.

61. Lundquist R, Dziegiel MH, Agren MS. Bioactivity and stability of endogenous fibrogenic factors in platelet-rich fibrin. Wound Repair Regen. 2008;16:356-63. 
62. He L, Lin $Y$, Hu X, Zhang $Y$, Wu H. A comparative study of platelet-rich fibrin (PRF) and platelet-rich plasma (PRP) on the effect of proliferation and differentiation of rat osteoblasts in vitro. Oral Surg Oral Med Oral Pathol Oral Radiol Endod 2009; 108: 707-13.

63. Del Corso M, Sammartino G, Dohan Ehrenfest DM. Re:Clinical evaluation of a modified coronally advanced flap alone or in combination with a platelet-rich fibrin membrane for the treatment of adjacent multiple gingival recessions: a 6-month study. J Periodontol 2009; 80: 1694-1697; author reply 1697-9.

64. Dohan Ehrenfest, DM, de Peppo, GM, Doglioli P, Sammartino $G$. Slow release of growth factors and thrombospondin-1 in Choukroun's platelet-rich fibrin (PRF): a gold standard to achieve for all surgical platelet concentrates technologies. Growth Factors 2009; 27: 63-9.

65. Simonpieri A, Del Corso M, Sammartino G, Dohan Ehrenfest DM. The relevance of Choukroun's platelet-rich fibrin and metronidazole during complex maxillary rehabilitations using bone allograft. Part I: a new grafting protocol. Implant Dent 2009; 18: 102-11.

66. Simonpieri A, Del Corso M, Sammartino G, Dohan Ehrenfest DM. The relevance of Choukroun's platelet-rich fibrin and metronidazole during complex maxillary rehabilitations using bone allograft. Part II: implant surgery, prosthodontics, and survival. Implant Dent 2009; 18: 220-229.

67. Sezgin Y, Taner L. Trombositten zengin fibrin ve dental uygulamalarda kullanımı. J Dent Fac Ataturk Uni 2012; 22: 325-33

\section{Yazışma Adresi}

Yrd. Doç. Dr. Serap KARAKIS

İstanbul Aydın Üniversitesi

Diş Hekimliği Fakültesi

Florya Yerleşkesi Beşyol Mah

.İnönü Cad.Akasya Sk. No:6

K.çekmece / İST

02124113000-dahili-29530

serapkarakis@aydin.edu.tr 